\title{
EDITORIAL
}

\section{Paradigms and Critical Learning}

\author{
Rob van Gestel
}

Law may be seen as a 'discipline in transition'. At least, this is what the latest Dutch research assessment exercise tells us in the report 'Quality and Diversity'. ${ }^{1}$ The committee, named after its chairman A.W. Koers, confronts the reader with a list of developments that constitute the core of this transition in research but, so I add, will similarly affect legal education. According to the committee, law is moving, among others from a national to an international or transnational discipline, from monodisciplinarity to multidisciplinarity, from individualism towards research programming, from being a service towards legal practice towards a purpose in itself, from implicit traditions towards more attention for methodology. ${ }^{2}$

It is amazing how little attention this introductory part of the research assessment exercise has received in the scholarly legal community, especially since the developments the committee describes might very well be called 'paradigmatic'. To give just one example: let's assume, for the sake of argument, that the committee is right and that law as an academic discipline is no longer first and foremost focused on legal practice and legal practitioners, especially the ones wearing robes. ${ }^{3}$ How will this affect both research and education? The various contributions in this issue of Law and Method try to shed light on this matter.

In 'Kuhn and Legal Research', Bald de Vries takes what he calls a reflexive paradigmatic view on legal research to recognize and understand paradigmatic changes in law and legal research. Taking as his point of departure the distinction that Kuhn makes between 'normal' and 'revolutionary' science, De Vries shows how the current frame of reference for students and legal researchers is based on a tacit understanding of certain assumptions about law itself (nation-state orientation), its function (problem solving) and the problems it addresses (e.g., the consequences of industrialization). If I understand him correctly, De Vries argues that a first step in recognizing possible 'anomalies' that may lead to 'revolutions' and 'paradigm shifts' in scholarly legal research is to make these implicit contextual assumptions more explicit in order to be able to question them. At first sight, it seems hard to disagree with this notion, but disagreement may arise once we ask ourselves what the practical consequences of the observations by De Vries should be.

1 Evaluatiecommissie Rechtswetenschappelijk onderzoek 2009. The report has an English summary.

2 Evaluatiecommissie Rechtswetenschappelijk onderzoek 2009, p. 6.

3 I mean of course the judiciary and the bar. See also Dworkin 2008. 
Why, for example, do most law school curricula at the moment reserve little or no time to making students familiar with what science and scholarship is all about? How come that students in (other) social sciences are trained in different research methodologies from the first year onward, whereas in law school methodology training usually is restricted to finding legal sources, training argumentative skills (e.g., moot courts) and, if one is lucky, perhaps an introduction to 'academic legal writing'? It is not surprising then that most law students have difficulties recognizing the different role models in law and legal research, such as advocates and judges, legislators and legal scholars. ${ }^{4}$ Confusion between these roles may, however, have unexpected negative consequences. For example, once legal scholars start to behave like advocates collecting evidence to support a certain claim without keeping an open eye to counter-evidence and counterarguments, they are - unconsciously - crossing boundaries between different discourses. This is where trouble lies in wait. As Robert Spitzer has argued in his thought-provoking book Saving the constitution from lawyers, ${ }^{5}$ one may seriously doubt whether 'advocacy scholarship' is scholarship at all, since a critical attitude and an openness towards the fact that one can always be wrong as a scholar are missing.

At this point Bart van Klink's claim that legal education should promote critical thinking by students in order to develop their faculty of judgement enters the picture. In his opinion it is of the utmost importance to make law students (more) aware of the fact that "knowledge is always a temporary and fallible construction and that it has - as soon as it is accepted and becomes naturalized and fixed as truth - a huge impact on our convictions and actions'.

Introducing them to ideas, such as in Kuhn's Structure of Scientific Revolutions, appears to be unavoidable from this perspective because it is a precondition for students to be able to reflect critically on existing legal paradigms. After all, one first has to know that something like an existing legal paradigm exists before being able to reflect on it. Although Van Klink stresses the importance of 'metajuridical courses', such as sociology, legal philosophy, and legal history (and methodology?), he also acknowledges the importance of providing students with 'a representative overview of the law as it is (according to some authoritative interpretation)'.

The latter should not be done to politicize the classroom, according to Van Klink, but to 'make students understand the law in its present state so they can make their own assessment of it'. I wonder whether this does not reveal an interesting normative starting position, namely that law school training should not be seen primarily as a service to legal practice - as it still is today? - but as a purpose in itself as the Koers' Committee formulated it. What should be the practical consequences for legal education? Should we, for example, try to get rid of the criteria for getting a law degree as imposed by the bar or by the government (in Dutch:

4 About these role models, see Van Dijck, Van Gulijk \& Prinsen 2010.

5 Spitzer 2008. 
'civiel effect')? A truly thought-provoking idea as it might open a new kind of competition among law schools. Currently the competition between law schools is limited due to the minimum criteria that are being set by the government to get a degree, which in its turn functions as a license to operate as a practicing lawyer. If we loosen the tight grip of legal practice on the law school curriculum, it would probably increase competition and stimulate diversity in the courses being offered to students. Some faculties would probably choose a strong practice- or business-oriented profile, whereas others might follow more of a liberal arts model. Students and faculty would really have something to choose, whereas currently the law school curriculum is rather uniform. Law schools that cannot choose could perhaps opt for a broad bachelor curriculum with lots of meta-juridical courses and attention for extra-legal knowledge and 'law and ...' courses, followed by master programmes with a far more practice-oriented profile (e.g., a 'toga master', a 'master in legislation and regulation' or a 'company lawyer master').

One wonders whether we are not already on the verge of a paradigm shift here. In other countries we observe that some law schools are developing a more transnational or 'global law' profile aiming for students who want to build an international career. A counterargument might be that Europeanization and internationalization are an absolute must for every law school today. Though this certainly holds true, there is a difference between offering courses in which the European and international context are strongly interwoven with positive national law, and aiming for training programmes that try to go beyond European and international law towards a transnational or global perspective on law and legal research. Although I must admit that I don't have a clear idea yet what 'global law' entails, I do see attempts to step away more from law and legal systems as nation-state oriented. ${ }^{6}$ Perhaps the contribution by Rudolf Rijgersberg and Hester van der Kaaij, 'A Plea for Rigorous Conceptual Analysis as a Central Method in Transnational Law Design' may shed light on what such a curriculum might look like in terms of content. They argue that although shared legal problems are generally easily identified in transnational law design it is considerably more difficult to design frameworks that transcend the peculiarities of local law univocally'. Rijgersberg and Van der Kaaij illustrate this by reflecting on the concept(s) of 'contract' in the model rules of the Draft Common Frame of Reference (DCFR). Their article shows that if one moves away from the paradigm of law as a product for national legal systems, one almost automatically enters the world of meta-juridical thinking in which the 'laws of law-making' as such become more important, since there is no longer a clear hierarchy of norms. Rijgersberg en Van der Kaaij claim that in addition to using historical and comparative methods in constructing new legal frameworks, rigorous conceptual analysis should play a more prominent role in developing transnational legal frameworks, such as the DCFR. They believe that we need to step beyond the legal rules and concepts of national systems, because otherwise ambiguities in rules and concepts are likely to permeate the whole 
framework. One might even go one step further. Is it a coincidence that 'grand codification projects', such as the European constitution and the European civil code, seem to have ended in a deadlock situation in which there is no/not enough political support? ${ }^{7}$ Could it be that the days of the big nineteenth-century type of codifications are over, exactly because globalisation urges us to be more modest in designing semi-permanent general legal rules, which are supposed to express the existing morals and custom as they grew bottom-up from society? If so, would that not be a truly revolutionary thought that urges us to rethink law-making all together?

\section{References}

\section{Arthurs 2009}

Harry W. Arthurs, 'Law and Learning in an Era of Globalization', German Law Journal, Vol. 10, no. 7 (2009), p. 629-640, at 635.

Van Dijck, Van Gulijk \& Prinsen 2010

G. van Dijck, S. van Gulijk \& M.M. Prinsen, 'Wat doen juridische onderzoekers? Een empirische blik', Recht der Werkelijkheid, Vol. 31, No. 1 (2010), p. 44-64.

\section{Dworkin 2008}

Ronald Dworkin, Justice in Robes, Harvard: Harvard University Press 2008.

Evaluatiecommissie Rechtswetenschappelijk onderzoek 2009

Kwaliteit \& Diversiteit. Rechtswetenschappelijk onderzoek in Nederland. Rapport van de Evaluatiecommissie Rechtswetenschappelijk onderzoek 2009. Amsterdam: Vrije Universiteit 2009 (<www.ru.nl/publish/pages/518190/rapport_ero.pdf〉).

\section{Kuhn 1996}

Thomas S. Kuhn, The Structure of Scientific Revolutions (3rd ed.), Chicago: University of Chicago Press 1996.

\section{Micklitz 2010}

Hans W. Micklitz, 'Failure or Ideological Preconception - Thoughts on Two Grand Projects: The European Constitution and the European Civil Code', EUI working paper, Law 2010/04.

\section{Smits 2011}

Jan Smits, 'European Legal Education or: How to Prepare Students for Global Citizenship', The Law Teacher, Vol. 45 (2011), p. 163-180.

\section{Spitzer 2008}

Robert J. Spitzer, Saving the Constitution from Lawyers. How Legal Training and Law Reviews Distort Constitutional Meaning, Cambridge: Cambridge University Press 2008. 